I think that the time has arrived for pricking this babble once for all, for the dissemination of this report can only give unnecessary trouble to the writers of the history of medicine. In exposing this fallacy I do not pretend to deny that syphilis may have occurred in Egypt in ancient times all that I can state is that among many thousands of ancient Egyptian skeletons I have never met with a single case which competent observers will agree to call undoubted syphilis.

$$
\text { I am, Sirs, yours faithfully, }
$$

G. Euliot SMith.

Anatomical Department. The School of Medicine, Cairo, Dec. 7th, 1907

\section{OBSTETRIC RARITIES IN GENERAL PRACTICE.}

To the Editors of THस LANCET.

SrRs,-In making brief reference to the following cases it is simply to draw attention to the somewhat infrequent occurrence of such consecutive rarities. Even in hospital practice I do not think such a sequence is by any means cornmon, but in private practice I should imagine it is extremely unusual. Hence my record of them. To be brief, they were a placenta prævia, a carneous mole, and an hydrencephalocele, the three occurring on consecutive days, In neither case was there any special feature worthy of particular comment, except the fact that the hydrencephalocele was one of precipitate delivery. This, I take it, is most unusual in so much as at least one cranial diameter (in this the suboccipito-bregmatic) was materially increased. When called to the case I found the child lying dead in a "chamber" which was half full of blood. The cord had ruptured and I am of opinion that death was due to loss of blood. In the occipital region was a large tumour which proved on examination to be a hydrencephalocele. On dissection I found the subarachnoid space full of fluid and the greater part of both hemispheres with much dilated ventricles projecting into the sac through an almost circular hole in the supra-occipital. On introducing the finger the tentorium could be felt below.

With regard to the placenta privia, I think the fact that the placenta, although almost central, was with no great difficulty displaced, allowing of a comparatively easy application of forceps, might also bear passing reference. In this case I had thought of turning, but the desire to hasten the termination of the labour suggested to me immediate instrumental interference. The mother made a good recovery but the child being premature (six and a half months) only lived six hours. The case of carneous mole pre sented the usual history. I first saw the patient on Oct. 1st when she was presumably in her fourth month of pregnancy. On that date she had a "show." I saw her again on Dec. 5th when she had had another " show." She had never felt any movements. Next day something came away, which, as might have been anticipated, proved to be a carneous mole. Possibly I have been somewhat prolix in my remarks concerning the above occurrences, but, as I have before mentioned, I think their rarity as a sequence in private practice warrants their description.

I am, Sirs, yours faithfully,

EDWARD TOWNSEND TUCKEY, M.B. R.U.I.

St. Stephen's-road, Bow, Dec. 10th, 1907.

\section{ANTHRAX-INFECTED CARCASS AS HUMAN FOOD.}

To the Editors of THW LANCHT.

SIRS, - The following may be of interest as an instance of the carcass of a bullock affected with undoubted anthrax having been eaten apparently without ill-effects ; and also of the practice too prevalent in country districts, of a sick animal being slaughtered, as it is said, "to save its life," so that it might be sold for human food.

A man was admitted into the Royal Surrey County Hos pital on Nov. 26th suffering from malignant pustule of four days' growth, on the anterior aspect of the left forearm. The pustule was excised and from it a smear was taken for direct examination and aerobic cultures in broth and on serum were made, both methods revealing the presence of anthrax bacilli. The man reluctantly gave a history of having assisted a butcher in dressing a bullock which had been found to be very ill on the morning of Nov. 9 th and which had been hurriedly slaughtered by a neighbouring cattle-dealer as it lay in the shed. A butcher who is in a large way of business in a neighbouring district was sent for to dress the animal, and he bought the whole of the carcass. He remarked that the spleen was abont eight times the normal size and left it on the premises for the owner to examine. This spleen was subsequently unearthed by the county veterinary inspector who found the anthrax organism in smear preparations. The butcher denied noticing that the blood was dark in colour and asserted that the animal was well nourished and that the flesh appeared perfectly sound. He first cooked a piece of the meat for his own table and finding nothing abnormal in the taste proceeded to sell the remainder. No case of illness has been reported as attributable to the meat, but it was found impossible to obtain a list of the customers to whom it had been sold. As previously mentioned, the pustule was first noticed exactly a fortnight after the handling of the carcass. It subsequently transpired that another man who assisted the butcher at the same time and who had cut his thumb the day before and injured the other thumb during the handling of the carcass developed symptoms of septicæmia a week later-i.e., on Nov. 16th-and died on Nov. 19th

It is anomalous that the only way the matter could be brought home to any of the parties concerned would be by prosecution of the owner by the County Council for failing to notify the occurrence of anthrax on his farm. He, of course, pleads ignorance of the nature of the illness; even then there remains the fact of the animal, whilst obviously moribund, being slaughtered for human food. The local authority can only deal with unsound meat by having it actually seized and condemned. As all the meat in this case had been eaten before the facts came to light no punishment, except that of publicity, seems possible.

I am, Sirs, yours faithfully,

Guildford, Dec. 14th, 1907.

R. W. C. PIERCE,

Medical Officer of Health.

\section{A CASE OF SELF-INDUCED (?) ABORTION. \\ To the Editors of THE LANCET.}

Sirs,-Dr. A. B. M. Thomson in THE LANCET of Sept. 7th asks under this title if it is possible for a woman to introduce into her uterus without causing injury to the vaginal walls or os a straight rigid rod four inches in length. During the last 12 months I have had two cases of the kind. In one a girl introduced a bone crochet needle five inches long into the uterus and successfully induced abortion at three months. I removed the needle and she aborted the next day and did well. In another case a married woman introduced a large hair-pin, four inches long, points upward, into the uterus and lost it. I dilated, removed the hair-pin, and curetted. She was six weeks pregnant. A week later she developed acute pelvic peritonitis and had to be opened and drained through the abdominal wall and Douglas's pouch and eventually did well.-I am, Sirs, yours faithtully,

Dubbo, Oct. 22nd, 1907. William DaIsh, M.D.

\section{THE OPHTHALMOMETER AND ITS LIMITATIONS. \\ To the Editors of THE LANCET.}

SIRs,-In the interesting annotation under the above heading which appeared in THE LANCET of Dec. 7 th there are some statements which seem to require amplification.

First, as to the claim that the ophthalmometer "was designed by Helmholtz for measuring the refracting surfaces of the eye," I would point out that, many years before, the curvature of the living cornea had been ascertained by the immortal Thomas Young, and described in his classical work "On the Mechanism of the Eye," published in the Philosophical Transactions for 1801 . He measured the diameter and height of his own cornea, viewing it in a mirror, and from the chord and sagitta so obtained he calculated the radins of the corneal sphere to be $\frac{31}{10}$ ths of an inch (7.87 millimetres). His striking accuracy is shown by the fact that it is the mean of later investigations which have limited the variations to between $7 \cdot 2$ and $8 \cdot 4$ millimetres. But although Young's work suffices for our knowledge of the cardinal points of the dioptric system the procedure could not be employed clinically.

Modern ophthalmometry is based on the physical properties 